\title{
ІНФОРМАТИЗАЦІЯ ВИЩИХ НАВЧАЛЬНИХ ЗАКЛАДІВ МЕДИЧНОГО НАПРЯМУ
}

\author{
О. П. Мінцер \\ Національна медична академія післядипломної освіти імені П. Л. Шупика
}

\begin{abstract}
Розглянуто питання інорорматизації вищих навчальних закладів медичного напряму, впровадження технології змішаного навчання з метою підвищення конкурентоспроможності українських медичних університетів, широкого застосування електронного навчання, управління електронним навчанням; інфрормаційну та методологічну підтримку розроблення навчального контенту. Підкреслюється, що альтернативи інформатизації закладів освіти сьогодні не існує, а головною метою інформатизації медичних вищих навчальних закладів має стати забезпечення гармонізації між потребами ринку в медичних і фрармацевтичних спеціалістах із визначеними компетенціями, зі світовими тенденціями та результатами функціонування вищих навчальних закладів.
\end{abstract}

Ключові слова: інформатизація вищих медичних навчальних закладів, інорормаційні технології, напрями інформатизації, віртуальна інтеграція наукових досліджень, трансдисциплінарність, математичне, імітаційне та комп'ютерне моделювання, онтологічні моделі знань.

\section{THE INFORMATISATION CONCEPT OF HIGHER MEDICAL UNIVERSITIES}

O. P. Mintser

\section{Shupyk National Medical Academy of Postgraduate Education}

The issues of informatisation of higher educational establishments of the medical field, introduction of mixed learning technology, in order to increase the competitiveness of Ukrainian medical universities, the widespread use of e-learning, electronic learning management, information and methodological support for the development of educational content are considered. It is emphasized that there are currently no alternatives to informatisation of educational institutions, and the main goal of informatisation of higher education institutions in the medical field should be to ensure harmonization between market needs in medical and pharmaceutical specialists with specific competencies, with world tendencies and results of functioning of higher educational institutions.

Key words: informatisation of higher medical educational universities, information technologies, informatisation directions, virtual integration of scientific researches, transdisciplinary, mathematical, simulation and computer modeling, ontological models of knowledge.

\section{ИНФОРМАТИЗАЦИЯ ВЫСШИХ УЧЕБНЫХ ЗАВЕДЕНИЙ МЕДИЦИНСКОГО НАПРАВЛЕНИЯ}

О. П. Минцер

Национальная медицинская академия последипломного образования имени П. Л. Шупика

\begin{abstract}
Рассмотрены вопросы информатизации высших учебных заведений медицинского направления, внедрение технологии смешанного обучения с целью повышения конкурентоспособности украинских медицинских университетов, широкого использования электронного обучения, управления электронным обучением; информационная и методологическая поддержка разработки учебного контента. Подчеркивается, что альтернативы инорорматизации учебных заведений в настоящее время не существует, а главной целью инфрорматизации медицинских высших учебных заведений должно стать обеспечение гармонизации между потребностями рынка в медицинских и фрармацевтических специалистах с определенными компетенциями, с мировыми тенденциями и результатами фрункционирования высших учебных заведений.
\end{abstract}

Ключевые слова: информатизация высших медицинских учебных заведений, информационные технологии, направления инорорматизации, виртуальная интеграция научных исследований, трансдисциплинарность, математическое, имитационное и компьютерное моделирование, онтологические модели знаний. 
Вступ. Інформатизації університетів присвячено багато досліджень [5-7]. Водночас слід підкреслити, що в питаннях інформатизації освіти, створення систем передавання знань, конструювання розгалужених знань Україна суттєво відстає від країн Європейського союзу. Проте, альтернативи інформатизації закладів освіти не існує, можливі лише різні темпи її впровадження, що залежить як від рівня фінансування, так і фахової підготовки науково-педагогічних працівників.

Стрімкий розвиток інформаційних технологій, рух України до євроінтеграції обумовили потребу розроблення концептуальних засад збору, збереження, обміну інформацією, принципів її захисту та застосування [1]. Відповідно, виникла потреба в створенні Концепції інформатизації вищих навчальних закладів (далі - Концепція).

Інформатизацію вищих навчальних закладів (ВН3) медичного профілю запропоновано планувати в п'яти основних взаємопов'язаних напрямах.

Перший напрям - комп'ютеризація освітнього процесу, використання сучасних інформаційних технологій для модернізації педагогічного процесу. Основна парадигма - поступовий перехід від традиційних форм передавання знань, потім до впровадження технологій змішаного навчання та, нарешті, з метою підвищення конкурентоздатності українських медичних університетів широкомасштабне застосування інформаційних технологій: дистанційного навчання, електронного, мобільного та всеохоплюючого навчання. Відповідно, необхідною стає масштабна модернізація освітнього процесу, що обумовлена як новими вимогами, які висуваються до сучасної системи освіти, так і постійним удосконаленням комп'ютерної техніки та мереж, а також суттєвим збільшенням обсягів інформації та новими завданнями її оброблення. Цей напрям реалізується шляхом інтеграції в інформаційне середовище ВН3 електронних засобів навчання, зокрема електронних освітніх ресурсів, а також програмних платформ систем управління навчанням (LMS - Learning Management Systems) та електронних бібліотек.

Другий напрям - комп’ютеризація системи академічного менеджменту шляхом автоматизації та інтелектуалізації бізнес-процесів. Цей напрям $є$ важливим і актуальним, оскільки спрямований на підвищення якості освітнього процесу в умовах зниження матеріальних витрат на організацію роботи ВНЗ. Він пов'язаний із розробленням і впровадженням спеціалізованих програмних платформ комп’ютеризації академічного менеджменту.
Третій напрям - інформатизація процесів надання медичної допомоги працівниками вищих навчальних закладів. Забезпечується спеціальною системою оцінювання якості надання медичної допомоги.

Четвертий напрям - реалізація завдань створення інноваційного закладу з подальшим прагненням до дослідницького університету. Цей напрям реалізується шляхом віртуальної інтеграції наукових досліджень, забезпечення їх трансдисциплінарності, математичного, імітаційного та комп'ютерного моделювання з подальшим поєднанням освіти, науки та інновацій, інтеграції у світовий освітньо-науковий простір.

П'ятий напрям - докорінна зміна контенту освіти та професійних обов'язків педагогічних i науково-педагогічних працівників, медичних, фармацевтичних і технічних спеціалістів. Один iз найважливіших напрямів, без якого практично неможливо здійснення глобальних завдань інформатизації ВНЗ. Складність напряму полягає в необхідності постійного оновлення навчального змісту [6], щоб віддзеркалити авангард результатів розвитку професійних дисциплін та їх останні тенденції. Відповідно науково-педагогічним працівникам (НПП) профільних дисциплін слід забезпечити своєчасну інтеграцію інформаційних технологій у викладання. Абсолютно необхідно використання різноманітних каналів для підвищення рівня інформаційних знань суб'єктів навчання. Методи навчання персоналу повинні бути різноманітними. Викладання повинно не обмежуватися заняттями в аудиторії, а й застосовувати різноманітні інформаційні платформи.

Суб' єкти навчання повинні розуміти суспільство, спілкуватися з суспільством і адаптуватися до нього. Для цього вони мають повною мірою скористатися багатими освітніми ресурсами університетів, логікою стажувань, виробничої практики, університетським науковим співробітництвом.

У Концепцію закладено основні принципи взаємодії структур ВНЗ при отриманні, збереженні та обробленні інформації, що відповідають вимогам чинного законодавства України.

Мета дослідження: інтеграція сучасних уявлень про процеси інформатизації університетів взагалі та вищих навчальних закладів медичного напряму особливо.

Результати та їх обговорення. Загальні положення. Абсолютно очевидно, що Концепція інформатизації вищих навчальних закладів має 
відповідати Законам України «Про Національну програму інформатизації» від 04.02.1998 № 74/98ВР із змінами, «Про Основні засади розвитку інформаційного суспільства в Україні на 20072015 роки» від 09.01.2007 № 537-V, «Про вищу освіту» від 01.07.2014 № 1556-VII, «Про інформацію» від 02.10.1992 № 2657-XII, «Про захист інформації в автоматизованих системах» від 05.07.1994 № 80/94-ВР, «Про електронні документи та електронний документообіг» від 22.05.2003 № 851-IV, «Про електронний цифровий підпис» від 22.05.2003 № 852-IV, «Про захист інформації в інформаційно-телекомунікаційних системах» від 31.05.2005 № 2594-IV, «Про захист персональних даних» від 01.06.2010 № 2297-VI; Указів Президента України: «Про заходи з розвитку національної складової глобальної інформаційної мережі Інтернет та забезпечення широкого доступу до цієї мережі в Україні» від 31.07.2000 № 928/2000, «Про першочергові завдання щодо впровадження новітніх інформаційних технологій» від 20.10.2005 № 1497/2005; наказів Міністерства освіти та науки України «Положення про дистанційне навчання» від 25.04.2013 № 466, «Про затвердження Вимог до вищих навчальних закладів і закладів післядипломної освіти, наукових, освітньо-наукових установ, що надають освітні послуги за дистанційною формою навчання з підготовки та підвищення кваліфікації фахівців за акредитованими напрямами і спеціальностями» від 30.10.2013 № 1518; ДСТУ 3396 0-96 «Захист інформації. Технічний захист інформації. Основні положення» та інших нормативних документів.

Концепція визначає характеристику сучасного стану інформатизації, цілі, завдання, пріоритетні напрями інформатизації, основні принципи формування та виконання програми, очікувані наслідки її реалізації.

У Концепції наведені нижче терміни та поняття вживаються у такому значенні:

- інформаційний простір ВНЗ - сукупність засобів інформатизації та інформаційних ресурсів, об’єднаних в єдину систему;

- суб'єкти інформатизації - замовники робіт (послуг) з інформатизації, виконавці окремих завдань (проектів) інформатизації, організації, що здійснюють експертизу окремих завдань і проектів інформатизації; користувачі автоматизованих та інших інформаційних систем і засобів інформатизації;
- інші наведені у Концепції терміни та поняття вживаються у значеннях, визначених Законом України «Про Національну програму інформатизації», Законом України «Про Основні засади розвитку інформаційного суспільства в Україні на 2007-2015 роки», Законом України «Про захист інформації в інформаційно-телекомунікаційних системах».

Аналіз стану інформатизації та пріоритетних напрямів розвитку в вищих навчальних закладах. У побудові інформаційного освітнього простору України останніми роками досягнуто суттєвих результатів:

- розпочато розроблення електронних реєстрів суб'єктів навчання в системі післядипломної медичної освіти (електронне портфоліо);

- розпочато роботи зі створення автоматизованої бази даних медичних, фармацевтичних, педагогічних і науково-педагогічних працівників у Міністерстві охорони здоров'я України;

- впроваджено системи дистанційного навчання, самонавчання та надання навчальних консультативних послуг;

- накопичено значний обсяг практичної, статистичної інформації щодо розроблення та впровадження інформаційних і телекомунікаційних систем;

- у деяких університетських клініках створено медичні інформаційні системи, інформаційні системи статистичного та довідкового спрямування.

Разом із тим існує низка проблем, вирішення яких необхідне для успішної реалізації заходів із інформатизації ВНЗ:

- інформаційний простір медичних університетів, зазвичай, фрагментований і децентралізований, що спричинено відсутністю єдиної стратегії їх розвитку;

- проблеми нормативно-правового регулювання інформатизації ВНЗ: а) відсутній повний обсяг необхідних галузевих нормативно-правових актів (зокрема, гармонізованих стандартів із медичної інформатики) щодо розроблення, впровадження, експлуатації та розвитку інформаційних ресурсів, інформаційних технологій і засобів інформатизації; б) відсутні формалізовані критерії визначення економічної ефективності впровадження та експлуатації інформаційних ресурсів і засобів інформатизації; - проблеми існуючих інформаційних ресурсів і засобів інформатизації: несумісність окремих 
видів інформаційних і телекомунікаційних систем, що обмежує можливість обміну інформацією між ними; відсутність кваліфікованого персоналу, необхідного для їх експлуатації;

- виражені проблеми: а) створення вузлів зберігання інформації (сервери, дата-центри): застарілість технічного оснащення; відсутність регламентів резервного копіювання інформації, що може спричинити ії безповоротну втрату; відсутність комплексної системи захисту інформації; нераціональне розташування таких вузлів, що ускладнює їх адміністрування; б) вдосконалення існуючих інформаційних мереж: низька розподільна здатність більшості використовуваних каналів зв'язку; в) низький ступінь захисту інформації у наявних інформаційних мережах;

- інформаційні медичні ресурси: недостатня кількість загальнодоступних якісних і достовірних спеціалізованих медичних інформаційних ресурсів;

- відсутнє цільове фінансування програми інформатизації у ВНЗ.

Мета Концепції. Головна мета Концепції - забезпечення гармонізації між потребами ринку в медичних і фармацевтичних спеціалістах із визначеними компетенціями, зі світовими тенденціями та результатами функціонування вищих навчальних закладів; інформатизація процесів забезпечення якості управління закладом відповідно до вимог ISO 9001; визначення принципів застосування сучасних інформаційних технологій, інформаційних ресурсів і засобів інформатизації для забезпечення якісної, своєчасної та доступної медичної та фармацевтичної освіти; задоволення професійних інформаційних потреб працівників ВН3, а також досягнення ефективного управління за допомогою організації його розвинутого та ефективного інформаційного простору із подальшою інтеграцією до національних і світових університетських інформаційних систем [2].

Завдання та пріоритетні напрями інформатизації закладів освіти. Сучасна інформатизація університетів змінює практично всю їх діяльність, викликає глибокі зміни у викладацьких ідеях університету [3]. Функціонування поступово перетворюється на іншу модель передавання знань, що орієнтована на людину та інновації навчання, а не лише проходження навчальних курсів та ознайомлення з різноманітними освітніми та культурними ресурсами на підставі підручників.
Суттєво змінюється й роль викладача: від викладання знань предмету до керівництва освітою: суб'єкти навчання можуть зрозуміти не тільки базову інформацію про відповідну професійну або навчальну інформацію, але й у короткий час за допомогою інформаційних технологій (мережних структур, мультимедіа, інтерактивності) відкрити для себе перспективи розвитку спеціальності та знайти свій напрям розвитку. Викладачі повинні лише певною мірою дати обгрунтовані вказівки, щоб бути лідером навчання. Тільки в післядипломному медичному навчанні можна виділити такі особливості:

1. Забезпечення постійного моніторингу параметрів якості післядипломного навчання лікарів і провізорів, а також динаміки потреб у спеціалістах медичного та фармацевтичного напрямів на ринках України та Європи; достовірності та швидкості отримання інформації щодо різних аспектів організації навчального процесу з необхідною ступеневою деталізацією i, як наслідок, обгрунтованості й оперативності прийняття управлінських рішень, що безпосередньо впливають на виконання медичними університетами освітньої функції.

2. Зниження витрат на організацію освітньої діяльності шляхом оптимізації використання всіх ресурсів медичних університетів, підвищення продуктивності праці персоналу та ефективного управління наданням платних освітніх послуг.

3. Демократизація освітнього процесу, розвиток академічних свобод завдяки забезпеченню прозорості діяльності всіх суб'єктів, задіяних у вищих навчальних закладах — від суб'єктів навчання до керівництва закладу, створенню зручного інформаційного середовища для взаємодії суб'єктів освітнього процесу.

4. Забезпечення комплексного підходу до управління навчальним закладом, оптимізація процесів прийняття рішень, покращення комунікації всередині закладу та із зовнішнім середовищем, підвищення достовірності та доступності інформації про діяльність закладу для всіх суб'єктів системи управління, оптимізація чисельності персоналу та ефективне використання його робочого часу.

5. Обгрунтування та постійне вдосконалення політики щодо інформатизації медичних університетів, пов'язаної з розробленням і впровадженням новітніх інформаційних технологій 
(медичні інформаційні системи управління, «хмарні» технології, Грід-технології, телемедичні системи, системи дистанційного доступу з можливістю оброблення інформації, Інтернетнавчання; дистанційна освіта тощо), зі свого боку спрямованих на ліквідацію відставання від передових країн світу та прискорення входження в інформаційний простір міжнародного медичного освітянського співтовариства для підвищення якості та доступності медичної допомоги, розвитку медичної освіти та науки.

6. Моделювання бізнес-процесів та опису інформаційних потоків. Реінжиніринг більшості бізнес-процесів. Навчання персоналу та оперативне інформування колективу медичних університетів про нові загальнодоступні функції (електронні послуги). Усі бізнес-процеси мають бути реалізовані засобами програмно-апаратних комплексів на базі відповідних програмних модулів.

7. Прогнозування потреб у післядипломній освіті лікарів і провізорів.

8. Забезпечення інформаційної взаємодії між структурними підрозділами.

Принципи формування та виконання Програми інформатизації. Можна виділити 8 основних принципів формування стратегії інформатизації вищих навчальних закладів:

1. Загальна інформатизація, розроблення, вибір програмних продуктів і обладнання, необхідних для формування та розвитку інформаційного простору медичних університетів, здійснюється за умови їх відповідності єдиній технічній та організаційній політиці у сфері інформатизації.

2. Організація структури всіх засобів інформатизації, інформаційних технологій та інформаційних ресурсів, що входять до інформаційного простору вищих медичних навчальних закладів, реалізується за принципами системності, комплексності, узгодженості та сумісності.

3. Дотримання вимог законодавства щодо захисту інформації, зокрема персональних даних.

4. Побудова інформаційного простору медичних університетів здійснюється з урахуванням можливості максимального використання існуючих у цій сфері програмно-технічних засобів (передусім, власних).

5. Забезпечення сумісності освітніх медичних інформаційних систем і ресурсів
3 інформаційними системами та ресурсами інших державних відомств у частині спільного використання персональних даних і електронного обміну документами.

6. Підтримка конкуренції серед учасників ринку медичних інформаційних освітніх послуг.

7. Актуальними $€$ також питання розроблення стратегії формування та подальшого вдосконалення інформаційного простору медичних університетів як складової галузевої частини інформаційної структури держави та сукупності різноманітних структур і форм їх взаємодії щодо збору, оброблення, збереження, захисту, розповсюдження та використання різних видів інформації для підтримки прийняття грунтовних управлінських рішень, задоволення потреб лікарів, провізорів і науково-педагогічних працівників щодо питань медичної освіти.

Заходи організаційного забезпечення виконання Програми інформатизації. Найперше, розглядається правове забезпечення процесу інформатизації вищих навчальних медичних закладів, що передбачає розроблення та активне застосування існуючих нормативно-правових актів стосовно конфіденційності персональної інформації та даних, регламентів розподілу прав доступу до даних; впровадження електронного реєстру можливих суб'єктів навчання із забезпеченням захисту інформації; організацію дистанційного доступу користувачів до інформаційно-довідникових баз відкритого типу; впровадження електронного документообігу; використання освітніх інформаційних технологій; гармонізацію основних міжнародних стандартів обміну даними, зокрема медичними; адаптацію державної системи класифікаторів і кодування інформації до завдань навчального закладу.

Слід підкреслити, що питання інформатизації вищих навчальних медичних закладів можуть бути вирішені шляхом застосування (в необхідних випадках — розроблення) нормативно-правової бази 3 питань організації та врегулювання відносин у цій сфері; вдосконалення інформаційної інфраструктури; запровадження електронного реєстру працівників, електронного документообігу й електронного цифрового підпису; формування багаторівневих інформаційно-аналітичних систем; концентрації науково-технічного потенціалу зі створення сучасних високоінтелектуальних навчальних технологій; реорганізації системи 
підготовки та перепідготовки працівників на основі сучасних тенденцій розвитку інформаційних технологій і технологій навчання; ефективного міжнародного співробітництва.

Формування інформаційної освітянської інфраструктури в медичних ВНЗ передбачає:

- розвиток інформаційно-аналітичних систем для аналізу якості надання освітніх послуг у цілому та за певними нозологічними напрямами, оцінювання ефективності діяльності факультетів, кафедр, окремих педагогічних і науково-педагогічних працівників;

- подальший розвиток інформаційно-аналітичних систем для введення єдиної методології обліку якості навчання медичних кадрів закладів охорони здоров’я на всіх рівнях, раціонального використання наявного кадрового потенціалу, достовірного планування потреби у навчанні, сприяння подальшому розвитку медичного освітнього простору України;

- інформаційна підтримка заходів із впровадження профілактичної моделі медичного обслуговування населення;

- створення та впровадження управлінських інформаційних систем, навчальних комп'ютерних програм, освітніх автоматизованих систем тестового контролю, систем дистанційного навчання, адаптивних технологій, телемедичних технологій тощо;

- організацію освіти суб’єктів навчання щодо роботи із засобами інформатизації, для чого необхідно реорганізувати професійну підготовку та перепідготовку педагогічних і науковопедагогічних працівників ВНЗ, розробити та впровадити нові навчальні програми з медичної інформатики відповідно до рекомендацій міжнародних організацій, передового світового досвіду з урахуванням сучасних тенденцій розвитку інформаційних технологій, засобів інформатизації і технологій навчання;

- вдосконалення кадрового забезпечення (зокрема, організація системи підготовки висококваліфікованого персоналу), необхідного для виконання завдань інформатизації у ВНЗ.

Інформація, що відноситься до публічного надбання, повинна бути легкодоступною та захищеною від незаконного змінювання. Для цього необхідно:

- створити постійно обновлювану та інтегровану з іншими базу персональних даних користувачів освітянських медичних послуг;
- розвинути існуючу систему збирання та оброблення статистичної інформації, зокрема, медичної;

- оновити систему обміну науковою інформацією із інтеграцією в сучасні світові бази наукової медичної інформації;

- розробити систему збору та формування баз даних вітчизняної наукової медичної інформації;

- створити документальні та фактографічні бази даних із відповідних підгалузей знань та за спорідненими напрямами;

- забезпечити сприяння створенню електронної бібліотеки;

- забезпечити доступ структур академії до електронних бібліографічних баз даних.

Інформатизація управління медичних ВН3 здійснюється шляхом:

1. Обгрунтування процесів інформатизації забезпечення якості управління відповідно до ISO 9001.

2. Розширення завдань маркетингу в бік постійного аналізу ринкових взаємовідносин і кількісного визначення потреб підготовки спеціалістів медичного та фармацевтичного напрямів із заданими характеристиками компетенцій і практичних навиків.

3. Суттєвого змінення принципів логістики навчальних послуг шляхом розширення використання методів дистанційного навчання, навчання на робочому місці, адаптивного та віртуального навчання, самонавчання тощо.

4. Інформаційного забезпечення сучасних форм управління (партисипативного, ризик-менеджменту, використання SWOT-аналізу, смартменеджменту тощо).

5. Забезпечення обліку та контролю за належністю, використанням і станом аудиторного, лабораторного, адміністративного та інших фондів, приміщень, за заселеністю та оплатою проживання в гуртожитках, облік задоволення заявок підрозділів ВНЗ на матеріально-технічне забезпечення навчального процесу та іншої їхньої діяльності.

6. Здійснення моніторингу інтегрованих даних про стан різних сфер діяльності навчальних закладів (фінансової, кадрової, навчальної), контроль виконання наказів і розпоряджень, аналіз ефективності діяльності всіх структурних підрозділів ВНЗ, аналіз ефективності прийнятих рішень. Облік вхідних, вихідних і внутрішніх документів, контроль виконання 
наказів, розпоряджень, ведення архіву документів, пошук документів в архіві, розсилка документів.

7. Забезпечення інтелектуального управління персоналом шляхом деталізованого обліку й аналізу стану, руху та прогнозних характеристик контингентів працівників, інтернів, аспірантів, клінічних ординаторів; формування статистичної та відомчої звітності, архіву; автоматизованого формування наказів і розпоряджень, графіків відпусток, планування та обліку підвищення кваліфікації всіх працівників академії, обліку лікарняних листів і аналізу захворюваності, обліку й аналізу заохочень та стягнень, відстеження термінів конкурсів і контрактів; обліку наукових публікацій, підготовки документів для атестації тощо.

Інформатизація навчально-методичної діяльності в медичних ВНЗ. Інформатизація навчально-методичної діяльності в закладах має надзвичайно широкі завдання. Змінюється практично все - від створення єдиного освітнього простору до можливостей персоналізації передавання знань. Наприклад, важливим напрямом застосування інформаційних технологій є кастомізація освіти налаштування в напряму «не так, як у всіх».

Процес кастомізації запускається спеціально на основі індивідуальних потреб до навчання. Кастомізація освіти пропонує змінити параметри навчального матеріалу та його викладання за бажанням суб’ єкту навчання.

Проте, можливе виділення загальних процесів, що передбачають інформатизацію навчально-методичної діяльності в медичних ВНЗ:

1. Використання сучасних інформаційних технологій для модернізації педагогічного процесу: дистанційного навчання (distance learning), електронного навчання (e-learning), мобільного навчання (m-learning), всеохоплюючого навчання (u-learning, ubiquitous learning), навчання на робочому місці, проблемо-орієнтованого навчання тощо.

2. Інтеграція в інформаційне середовище медичних ВНЗ електронних засобів навчання, зокрема електронних освітніх ресурсів, а також програмних платформ систем управління навчанням (LMS) та електронних бібліотек.

3. Впровадження автоматизованих смарттехнологій контролю знань (самоконтролю, модульного контролю, систем розгалуженого контролю знань, контролю зображень, систем прийняття рішень, видобутку знань, використання онтологічних моделей, застосування математичних моделей тощо).

4. Впровадження адаптивних систем навчання та контролю знань.

5. Застосування індивідуальних траєкторій навчання.

Слід підкреслити, що інформатизація освіти обумовлює низку викликів до ефективного викладання в університеті [8].

Деталізуючи сказане, слід зазначити, що потрібно забезпечити інформаційну диверсифікацію засобів навчання. Психологічні експерименти довели, що людина отримує понад 80 \% інформації з візуальних джерел, та лише близько 12 \% - від прослуховування. Відповідно зовсім іншого значення набувають сучасні мультимедійні технології і технології комп’ютерних мереж, що дозволяють суб’єкту навчання відчути себе часткою віртуального навколишнього середовища. Великого значення набувають системи доповненої реальності. Розширення взаємодії між викладачем та учнями забезпечується різноманітністю комунікаційних платформ для спілкування, культивуючи через двостороннє відео можливості аналізу та вирішення проблем [4].

Посилення підготовки інформаційної грамотності педагогічних і НПП висуває нові вимоги до компетенції інформаційної грамотності викладачів університетів.

Нові вимоги обумовлюють реформування оцінювання знань, уникаючи принципу «одного розміру підходить всім»: система оцінювання в університеті повинна враховувати розвиток особистості суб’єкта навчання, його щоденну роботу. В подальшому оцінювання має надавати велике значення відмінностям суб’ єктів навчання, їх особистості; прийняттю різноманітних методів оцінювання.

Інформатизація наукової діяльності передбачає декілька напрямів. Серед них найважливішими слід вважати:

1. Інформаційне забезпечення процесів пріоритетних напрямів розвитку науки та технологій.

2. Інформаційну підтримку розвитку новітніх технологій, що впроваджуються в сучасну охорону здоров’ я: нанотехнологій, робототехніки, симуляційної медицини, системної біології та системної медицини.

3. Забезпечення інформаційних зв'язків між навчальною та науковою діяльністю. 
4. Формування інформаційних зв'язків із академічною та галузевою наукою, а також виробництвом із урахуванням сучасних економічних умов.

5. Подальший розвиток інформаційно-комунікаційних технологій для підтримки впровадження наукових розробок працівників ВНЗ у вітчизняне виробництво, розвиток інноваційних зв’язків між університетами.

6. Інформаційну підтримку комерціалізації наукових досягнень, включаючи створення малих інноваційних компаній.

Інформатизація міжнародної діяльності. Інформаційне суспільство є глобальним за своєю суттю, тому завдання, що ставляться у вищих навчальних медичних закладах, повинні виконуватися за допомогою ефективного регіонального, державного та міжнародного співробітництва. Інформатизація міжнародної діяльності передбачає:

- інформаційне забезпечення процесів впровадження світового досвіду передавання знань (з урахуванням вітчизняних традицій медичної (фармацевтичної) освіти);

- формування інформаційних зв’язків із провідними світовими центрами післядипломної підготовки лікарів і провізорів;

- подальший розвиток інформаційно-комунікаційних технологій для забезпечення умов експертної привабливості наукових та освітніх програм закладу на основі інтеграції світових та академічних досягнень у медичній (фармацевтичній) освіті та забезпечення здоров’я населення;

- інформаційне забезпечення процесів використання світового досвіду підготовки «вузьких» спеціалістів: організація міжнародних віртуальних семінарів, віртуальних тренінгів, віртуальних виставок і презентацій.

Можна також виокремити співробітництво в області інформатизації охорони здоров'я з Міжнародною асоціацією медичної інформатики (IMIA) та Європейською федерацією медичної інформатики (EFMI), національним членом яких $€$ Україна, що буде сприяти вивченню та адаптації міжнародного досвіду з питань розвитку та застосування інформаційних технологій.

Інформатизація матеріально-технічної та фінансової діяльності передбачає: інформаційну підтримку постійного пошуку нових джерел фінансування та ресурсного забезпечення на основі ринкових механізмів; створення інформаційно-комунікаційної інфраструктури; інформаційне забезпечення процесів консолідації фінансових ресурсів на пріоритетних напрямах розвитку академії; подальший розвиток комп’ютерної бази закладу.

Окремо розглядається інформаційна підтримка аналітичного планово-фінансового управління, що дозволить здійснювати розрахунок середньооблікової і облікової чисельності, формування державної звітності, складання кошторисів, контроль за надходженнями та витратами коштів, укладання та облік договорів (з орендарями, іноземними слухачами, організаціями), контроль за виконанням зобов’язань за договорами, моделювання обсягів фінансування, формування штатного розкладу, розрахунок штатного розкладу тощо.

Очікувані результати інформатизації. Формування інформаційно-освітнього середовища покликане забезпечити перехід освіти на іншу якісну основу відповідно до майбутнього інформаційного суспільства. Зміна ключових компонентів педагогічної системи: змісту освіти, стратегії навчально-методичної роботи, методів і форми навчання, науково-методичного супроводу мають принести принципово нові результати, а саме:

1. Створення динамічно функціонуючої системи підготовки медичних і фармацевтичних кадрів, що постійно знаходиться в гармонізації з ринковими потребами за компетентнісними характеристиками, рівнем знань та практичними навиками.

2. Створення та розвиток інформаційного простору в конкретних медичних університетах, а в наступному — в сфері медичної освіти України забезпечить ефективне управління, аналіз та оброблення інформаційних потоків, зокрема на регіональному та на державному рівнях.

3. Підвищення якості та доступності навчання у вищих навчальних медичних закладах i в цілому в системі медичної освіти шляхом відмови від традиційних методик викладання: передавання знань відповідно до стандартів, уніфікованих методичних розробок (логіка «одного шляху») до «інформаційної взаємодії» викладацької громади з особистістю.

4. Підвищення якості передавання знань завдяки безперервному моніторингу параметрів якості навчання, обгрунтованості й оперативності прийняття управлінських рішень, що безпосередньо впливають на виконання у вищих 
навчальних медичних закладах освітньої діяльності.

5. Зниження собівартості освітніх та інших послуг, які надаються вищими навчальними медичними закладами, що досягається шляхом підвищення продуктивності й ефективності праці (зокрема завдяки усуненню дублюючих операцій, скороченню рутинної роботи, підвищенню швидкості оброблення інформації) та оптимізації чисельності, функціонального використання персоналу, ефективнішого використання матеріальних ресурсів тощо.

6. Підвищення ефективності управління ВНЗ, зокрема кадровим потенціалом, шляхом інформаційної підтримки прийняття аргументованих управлінських рішень, постійного автоматизованого моніторингу діяльності, достовірного прогнозування та контролю завантаження.

7. Удосконалення та оптимізація документообігу, управління потоками суб’єктів навчання та підвищення достовірності інформації.

8. Спрощення та прискорення процесів оброблення та аналізу аналітичної інформації за рахунок створення єдиної системи її кодування; підвищення ступеню достовірності сумуючої статистичної інформації.

9. Зменшення чисельності паперових форм у вищих навчальних медичних закладах; економія часу на їх заповнення та виключення помилок при ручному обробленні.

10. Прискорення впровадження в практику нових методів діагностики і лікування відповідно до стандартів надання медичної допомоги.

11. Підвищення рівня міжнародної співпраці в медичній освітній сфері шляхом інтеграції у всесвітній простір.

12. Ефективний аналіз навчальної діяльності на підставі отримання інтегрованих даних; контроль за виконанням педагогічного навантаження педагогічних і науково-педагогічних працівників; формування, виконання та аналіз програм і навчальних планів; формування планової кількості суб'єктів навчання на кафедрах; облік проходження практики суб’єктами навчання; планування й облік видання методичної літератури; планування й облік підвищення кваліфікації; ведення електронного журналу розпоряджень деканатами та дирекціями; автоматичне формування та друк вкладишів до сертифікатів, академічні довідки тощо.

13. Сучасний облік і контроль за наявністю, використанням і станом аудиторного, лабораторного, адміністративного та інших фондів і будівель ВНЗ (зокрема гуртожитків), облік задоволення заявок структурних підрозділів на матеріально-технічне забезпечення навчального процесу та іншої їхньої діяльності.

14. Подальший розвиток інформаційно-аналітичних систем для введення єдиної методології обліку якості навчання, раціонального використання наявного кадрового потенціалу, достовірного планування потреби у навчанні, сприяння подальшому розвитку медичного освітнього простору України.

15. Суттєве зменшення когнітивних та інших асиметрій у навчанні.

16. Стратегічне реформування навчально-методичної роботи на основі використання інтелектуальних алгоритмів визначення індивідуальних траєкторій навчання, якості засвоєння навчального матеріалу, «слабких місць» засвоєння, дефектів інтеграції знань, застосування онтологічних моделей міждисциплінарності та трансдисциплінарності передавання знань.

Фінансові, матеріально-технічні, трудові ресурси, необхідні для виконання програми інформатизації освіти. Ресурсне забезпечення у сфері освіти завжди було найважливішою ознакою реалізації проекту.

Фінансове забезпечення реалізації Концепції має здійснюватися за рахунок коштів закладу освіти, а також благодійних фондів, зацікавлених суб’єктів підприємницької діяльності всіх форм власності, громадських організацій, міжнародних фінансових організацій та інших джерел, не заборонених законодавством України.

Обсяги фінансування повинні розраховуватися, виходячи із реальних потреб забезпечення університету апаратно-програмними комплексами та їх компонентами, комунікаційними мережами, ліцензійними програмними засобами, витратами, пов'язаними із навчанням користувачів; з урахуванням передбачуваних інфляційних процесів.

Етапність впровадження Концепції. 3 метою відпрацювання методів взаємодії інформаційних мереж різного призначення, як на технічному рівні, так і на рівні використання інформації, пропонується забезпечити етапність впровадження Концепції. 
Традиційно передбачаються три етапи:

- 1-й етап: підготовка технічного завдання та техноробочого проекту. Поступове змінення контенту навчання та технологій навчання;

- 2-й етап: завершення процедур електронного документообігу. Впровадження елементів електронного управління. Створення єдиного навчального та наукового простору. Завершення змінення контенту навчання. Впровадження систем індивідуального навчання;

- 3-й етап: завершення виконання основних завдань інформатизації. Входження до єдиного всесвітнього навчального, наукового та соціального просторів. Використання міжнародних стандартів освіти.

\section{Висновки.}

1. Альтернативи інформатизації закладів освіти не iснує.

2. Головною метою інформатизації вищих навчальних закладів медичного напряму має стати забезпечення гармонізації між потребами ринку в медичних і фармацевтичних спеціалістах iз визначеними компетенціями, зі світовими тенденціями та результатами функціонування вищих навчальних закладів.

\section{Література.}

1. Концепція інформатизації охорони здоров’я України / О. П. Мінцер, Ю. В. Вороненко, Л. Ю. Бабінцева та ін. // Медична інформатика та інженерія. — 2012. № 3. - C. 5-29.

2. Мінцер О. П. Модель функціонування інформаційної системи підтримки єдиної галузевої освітньої мережі у вищих медичних (фармацевтичному) навчальних закладах IV рівня акредитації та закладах післядипломної освіти МОЗ України : методичні рекомендації / О. П. Мінцер, О. А. Рижов, В. П. Марценюк. — К.: МОЗ України, 2013. - 57 с.

3. Aurer B. Informatization and computerization at the university of Zagreb / B. Aurer, M. Sunjlć // Higher Education in Europe. — 1991. — Vol. 16, № 2. — P. 102107.

4. Fan J. Y. On the construction of management pattern of informationization in colleges and universities / J. Y. Fan // 3rd International conference on e-commerce and contemporary economic development (ECED 2017), Xi’an, Shaanxi, China, April 8-9, 2017. — P. 326-329.

5. Mu Li Z. Analysis the challenges of university teaching process brought by modern information technology / Z. Li $\mathrm{Mu} / /$ Journal of Inner Mongolia Normal University. 2011. — Vol. 24, № 7. — P. 1-5.
6. Wei Z. Discussion on the teaching management mode of university based on network informatization models / Z. Wei // Educational Forum. — 2012. — № 12. — P. 158159.

7. Wu S. Education informatization and university teaching reform / S. Wu, T. Na // International conference on education technology and information system (ICETIS 2013). — Atlantis Press, 2013. — P. 608-611.

8. Zhu Z.-w. Informatization construction of university teaching service system / Z.-w. Zhu, Y.-y. Guo // International conference of information technology, computer engineering and management sciences (ICM 2011), Nanjing, Jiangsu, China, 24-25 September 2011. — P. 211-214.

\section{References.}

1. Mintser, O. P., Voronenko, Yu. V., Babintseva, L. Yu. et al. (2012). Kontseptsiia informatizatsii okhoroni zdorov'ia Ukraini [The concept of informatization of health care in Ukraine]. Medichna informatika ta inzheneriia (Medical Informatics and Engineering), 3, 5-29.

2. Mintser, O. P., Rizhov, O. A., \& Martsenyuk, V. P. (2013). Model' funktsionuvannia informatsiinoi sistemi pidtrimki iedinoi haluzevoi osvitn'oi merezhi u vishchikh medichnikh (farmatsevtichnomu) navchal'nikh zakladakh IV rivnya akreditatsii ta zakladakh pislyadiplomnoi osviti MOZ Ukraini [Model of the functioning of the information system supporting a single branch educational network in higher medical (pharmaceutical) educational institutions of the IV level of accreditation and postgraduate institutions of the Ministry of Health of Ukraine]: guidelines. Kyiv.

3. Aurer, B., \& Sunjlć, M. (1991). Informatization and computerization at the university of Zagreb. Higher Education in Europe, 16(2), 102-107.

4. Fan, J. Y. (2017). On the construction of management pattern of informationization in colleges and universities. In 3rd International conference on e-commerce and contemporary economic development (ECED 2017) April 8-9, 2017 Xi'an, Shaanxi, China (p. 326-329).

5. Mu, Li Z. (2011). Analysis the challenges of university teaching process brought by modern information technology. Journal of Inner Mongolia Normal University, 24(7), 1-5.

6. Wei, Z. (2012). Discussion on the teaching management mode of university based on network informatization models. Educational Forum, 12, 58-159.

7. Wu, S., Na, T. (2013). Education informatization and university teaching reform. In International conference on education technology and information system (ICETIS 2013) (p. 608-611). Atlantis Press.

8. Zhu, Z.-w., Guo, Y.-y. (2011). Informatization construction of university teaching service system. In International conference of information technology, computer engineering and management sciences (ICM 2011). Proceedings of a meeting held 24-25 September 2011, Nanjing, Jiangsu, China (p. 211-214). 